\title{
DESENVOLVIMENTO IN VITRO DE PLÂNTULAS DE DIPLÓIDES DE BANANEIRA OBTIDAS A PARTIR DE CULTURA DE EMBRIÕES ${ }^{1}$
}

\author{
TÁRCIA DOS SANTOS NEVES²; SEBASTIÃO DE OLIVEIRA E SILVA; \\ ROBERTO PEDROSO DE OLIVEIRA ${ }^{3}$
}

\begin{abstract}
RESUMO - Este trabalho teve por objetivo avaliar o desenvolvimento in vitro de plântulas de progênies de oito genótipos de bananeira obtidos a partir de cultura de embriões. Os genótipos foram as espécies selvagens Calcutta e Malaccensis (Musa acuminataAA), Butuhan e França (M. balbisiana-BB) e os híbridos 0304-02, 1304-06, 4252-04 e 9379-09 (M. acuminata-AA). Os embriões foram extraídos de forma asséptica, sendo introduzidos em meio de cultura MS com $30 \mathrm{~g} \mathrm{~L}^{-1}$ agar, inicialmente em placas de Petri (40 dias) e depois em tubos de ensaio (45 dias). Verificou-se efeito do genótipo no desenvolvimento in vitro dos embriões. As progênies dos genótipos selvagens do grupo BB, seguidos das progênies dos híbridos AA apresentaram maior desenvolvimento para as variáveis estudadas. O protocolo utilizado foi adequado para a cultura de embriões das progênies dos oito genótipos, devendo, no entanto, o período de desenvolvimento in vitro ser reduzido para 30 dias a fim de que o enraizamento não seja muito acentuado.
\end{abstract}

Termos para indexação: Musa spp., híbridos, sementes, germinação in vitro.

\section{DEVELOPMENT OF IN VITRO DIPLOID BANANA PLANTLETS OBTAINED FROM EMBRYO CULTURE}

\begin{abstract}
The objective of this work was to evaluate the development of in vitro plantlets of progenies of eight diploid banana genotypes that were obtained from embryo culture. The genotypes were the wild species Calcutta and Malaccensis (Musa acuminataAA), Butuhan and França (M. balbisiana-BB) and the hybrids 0304-02, 1304-06, 4252-04 and 9379-09 (M. acuminata-AA). The embryos were aseptically, being introduced in MS medium with $30 \mathrm{~g} \mathrm{~L}^{-1}$ agar, initially in Petri dishes (40 days) and afterwards in test tubes (45 days). It was observed a pronounced effect of the genotype on the in vitro development of the embryos. The progenies of the wild genotypes of the BB group, followed by that of AA hybrids showed higher development for the studied variables. The protocol was appropriated for the embryo culture of progenies of the eight genotypes. However, in order to have a non accentuated rooting, the period of in vitro development should be reduced to 30 days.
\end{abstract}

Index terms: Musa spp., hybrids, seeds, in vitro germination.

\section{INTRODUÇÃO}

A bananicultura possui grande importância econômica e social, sendo cultivada numa extensa região tropical, geralmente por pequenos agricultores. O Brasil é o terceiro produtor mundial de banana, com produção aproximada 5,97 milhões de toneladas, numa área cultivada de 560 mil hectares (FAO, 1999).

Há mais de dez anos vem sendo conduzido na Embrapa Mandioca e Fruticultura um programa de melhoramento genético visando à obtenção de híbridos de bananeira resistentes a pragas e doenças, mais produtivos e que produzam frutos de melhor qualidade.

A técnica de hibridação controlada tem sido utilizada no melhoramento, sendo obtidas sementes dos cruzamentos entre diplóides (AA) e destes com cultivares comerciais do tipo Prata e Maçã ( $A A B)$, gerando, respectivamente, híbridos diplóides (AA) e tetraplóides (AAAB).

$O$ pequeno número de sementes obtidas nos cruzamentos e a baixa porcentagem de germinação, devido à dormência da semente ou má-formações do endosperma e/ou embrião, têm sido fatores limitantes à obtenção de materiais híbridos (Shepherd et al., 1994; Silva et al., 1997).

A técnica de cultivo in vitro de embriões tem sido utilizada com sucesso em inúmeros gêneros de plantas, permitindo a superação de barreiras genéticas à germinação $(\mathrm{Hu}$ \& Ferreira, 1990). No caso específico de bananeira tem possibilitado à obtenção de porcentagens de germinação superiores a $50 \%$, enquanto que, em viveiro, tem sido de apenas 1\% (Cox et al.,0 1960; Vuylsteke \& Swennen, 1991).

A eficiência da cultura de embriões é afetada pelo grau de maturidade fisiológica da semente, intensidade do tratamento de desinfestação, habilidade manual na extração dos embriões, orientação do embrião no meio de cultura, composição do meio de cultura, condições ambientais de cultivo, dentre outros fatores (Johri \& Rao, 1984; afele \& De Langhe, 1991, Neves et al., 1998, Silva et al 1999).

Segundo Raghavan (1980), a utilização de sementes fisiologicamente maduras requer apenas a presença de sais

1 (Trabalho 156/2001). Recebido: 22/10/2001. Aceito para publicação: 07/11/2001.

2 Mestre em Agronomia Área de Fruticultura - Escola de Agronomia da Universidade Federal da Bahia (EAUFBA), 44380-000, Cruz das AlmasBA.

3 Doutor em Melhoramento de Plantas, Pesquisador da Embrapa Mandioca e Fruticultura, Cx.P. 007, 44380-000, Cruz das Almas-BA.

4 Mestre em Melhoramento (Cultura de Tecidos), Pesquisador Embrapa Mandioca e Fruticultura, Cx.P. 007, 44380-000, Cruz das Almas-BA.

Rev. Bras. Frutic., Jaboticabal - SP, v. 24, n. 1, p. 006-009, abril 2002 
inorgânicos e sacarose no meio de cultura para a germinação e desenvolvimento dos embriões, devido possuírem estrutura bipolar desenvolvida e passarem rapidamente para o estado autotrófico.

$\mathrm{Na}$ literatura existem poucos trabalhos relativos à germinação de embriões de diplóides de bananeira (Cox et al., 1960; Stotzky et al., 1962; Vuylsteke \& Swennen, 1991; Chin, 1996, Silva et al., 1999), sendo que não relatam detalhes sobre o desenvolvimento in vitro das plântulas.

O resgate de híbridos, via cultura de embrião, tem sido uma prática rotineira no melhoramento de banana. Trabalhos conduzidos nesta área, tem mostrado uma grande influência materna na qualidade do endosperma e embrião, que a depender do cruzamento, chega a inviabiliar a recuperação do híbrido. Observou-se também que sementes oriundas de acessos selvagens de M. acuminata são mais viáveis que as de híbridos simples, que por sua vez apresentam maior viabilidade do que aquelas advindas de híbridos envolvendo mais de dois parentais (Silva, et al., 1999).

Este trabalho teve por objetivo avaliar o desenvolvimento in vitro de plântulas de progênies de oito genótipos diplóides de bananeira obtidas a partir de cultura de embriões.

\section{MATERIAL E MÉTODOS}

Foram utilizadas sementes de progênies de oito genótipos diplóides de bananeira, coletadas no Banco de Germoplasma da Embrapa Mandioca e Fruticultura, sendo duas espécies selvagens de Musa acuminata-AA (Calcutta e Malaccensis), duas selvagens de M. balbisiana-BB (Butuhan e França) e quatro híbridos de M. acuminata-AA 0304-02 (Calcutta x Madang), 1304-06 (Malaccensis x Madang), 4252-04 [M53 (híbrido da Jamaica) x Kumburgh] e 9379-09 [1741-01 (Jari Buaya x 0304-02) x 2803-01 (Tuu Gia x Calcutta)].

As sementes das progênies de cada genótipo, resultantes de polinização aberta, foram retiradas de frutos maduros de pelo menos 12 plantas, lavadas em água corrente, despolpadas e embebidas em água destilada por 24 horas.

A desinfestação das sementes foi realizada sob condições assépticas, em câmaras de fluxo laminar, sendo tratadas com nitrato de prata a $0,5 \%$ por 10 minutos e, em seguida com cloreto de sódio a $5 \%$, por 5 minutos. Após esse tratamento, foram realizadas três lavagens em água destilada esterilizada.

A extração dos embriões foi realizada em câmara de fluxo laminar, sob estereoscópio, sobre papel de filtro estéril, usando pinça e bisturi. Foram extraídos embriões de 100 sementes de cada genótipo, sendo inoculados in vitro quatro embriões, com o ápice voltado para cima, por placa de Petri $(25 \mathrm{~mm}$ x $100 \mathrm{~mm})$ contendo $10 \mathrm{~mL}$ de meio de cultura MS (Murashige \& Skoog, 1962) suplementado com $30 \mathrm{~g} \mathrm{~L}^{-1}$ de sacarose e $7 \mathrm{~g} \mathrm{~L}^{-1}$ de agar. Os embriões foram mantidos em câmara de crescimento sob condições de escuro e temperatura de $26 \pm 2^{\circ} \mathrm{C}$.

Quarenta dias após o início da germinação, trinta plântulas de cada progênie (genótipo), escolhidas ao acaso, foram introduzidos individualmente em tubos de ensaio $(25 \mathrm{~mm}$ x 150 $\mathrm{mm}$ ), para completarem o seu desenvolvimento in vitro. Esta fase foi conduzida em meio de cultura idêntico ao da fase anterior e sob condições de cultura de $26 \pm 2^{\circ} \mathrm{C}$, fotoperíodo de 16 horas e intensidade luminosa de 1600 lux.

Após 45 dias de cultivo foram realizadas avaliações da altura (medida do colo da plântula ao ponto de inserção da última folha aberta funcional), número de folhas, número de raízes, comprimento da maior raiz, peso seco da parte aérea e das raízes de cada plântula. Os dados de peso seco foram transformados para $\log (\mathrm{x}+1,5)$ antes da análise estatística. As variáveis foram comparadas pelo teste de Scott \& Knott (1974) ao nível de 5\% probabilidade. Nesta fase também foram avaliados os níveis de contaminação microbiana, oxidação e morte de plântulas.

Em seguida, as plântulas foram retiradas dos frascos e lavadas em água corrente. Foi feita a poda das raízes, deixandoas com um comprimento máximo de $6 \mathrm{~cm}$. O transplantio foi realizado em copinhos de $300 \mathrm{~cm}^{3}$, contendo substrato esterilizado a base de vermiculita, areia e matéria orgânica (1:1:1), sendo realizada a aclimatação em casa de vegetação.

\section{RESULTADOS E DISCUSSÃO}

Na Tabela 1 verifica-se o efeito da progênie do genótipo no desenvolvimento in vitro de plântulas de bananeira obtidas a partir do cultivo de embrião. As progênies dos materiais selvagens do grupo BB (Butuhan e França) apresentaram maior desenvolvimento in vitro quanto à altura, comprimento da maior raiz, peso seco da parte aérea e das raízes das plântulas em relação às progênies dos híbridos e materiais selvagens do grupo AA. Dentro desse grupo, as progênies de híbridos desenvolveram-se mais acentuadamente do que as oriundas de materiais selvagens (Calcutta e Malaccensis), o que pode ser atribuído ao vigor híbrido.

Dentre as progênies dos genótipos avaliados, a da Butuhan apresentou as médias mais elevadas para a maioria das variáveis estudadas, inclusive com diferença significativa pelo de teste de Scott \& Knott (1974) ao nível de 5\% de probabilidade (Tabela 1).

Os resultados bastante próximos de peso seco da parte aérea em relação ao da raiz revelam um desenvolvimento equilibrado das plântulas após a germinação. Durante a fase de desenvolvimento in vitro das plântulas houve um crescimento acentuado das raízes, principalmente nas duas últimas semanas de cultivo. O comprimento da maior raiz foi de três a seis vezes maior que a altura das plantas e o número de raízes também foi elevado, variando, em média, de 14 a 21 em função do genótipo. Em geral, as plântulas apresentaram de três a cinco raízes longas, sendo o restante pequenas $(<5 \mathrm{~cm})$. Parte das raízes longas apresentaram problemas de enovelamento, o que não comprometeu o transplantio devido à realização da poda. Segundo Oliveira \& Silva (1997), o excessivo desenvolvimento das raízes não se observa em plântulas de bananeira micropropagadas introduzidas em meio de cultura MS sem reguladores de crescimento, embora nesses casos deve haver efeito residual do BAP (benzilaminopurina) utilizado na fase de multiplicação. Embora o pegamento das mudas durante a aclimatação tenha sido elevado ( $>90 \%$ ), recomenda-se a redução do período de cultivo de 45 para 30 dias, para diminuir o crescimento das raízes. Afele \& De Langhe (1991) obtiveram plântulas com altura média de $3,1 \mathrm{~cm}$, número médio de raízes 
igual a 7,0 e comprimento médio das raízes de $3,5 \mathrm{~cm}$ em 30 dias de cultivo in vitro, as quais foram adequadas à aclimatação.

$\mathrm{O}$ desenvolvimento in vitro das plântulas depende do genótipo, da aplicação correta da técnica de resgate dos embriões e da adequação do meio e condições ambientais de cultivo (Johri \& Rao, 1984; Afele \& De Langue, 1991; Oliveira et al., 1998). Os resultados obtidos comprovam a eficiência do protocolo utilizado e o fato de não ser necessária a presença de reguladores de crescimento para a germinação e desenvolvimento in vitro de embriões maduros (Raghavan, 1980). Embora os embriões variem em tamanho e forma em função da espécie e variedade, existindo efeito do genótipo na germinação e desenvolvimento das plântulas, o protocolo pode ser utilizado com sucesso no resgate de embriões dos genótipos testados.

Durante a fase de desenvolvimento in vitro das plântulas houve uma porcentagem de contaminação de $15 \%$ a $20 \%$, originária, provavelmente, da própria manipulação do material sob condições in vitro. Apenas as plântulas contaminadas apresentaram nível de oxidação acentuado, seguido de morte das mesmas.

A análise da Tabela 2 permite verificar que as variáveis mais indicadas para se avaliar o desenvolvimento in vitro das plântulas são a altura e o peso seco das raízes e da parte aérea, entre as quais observou-se correlação positiva e significativa.

\section{CONCLUSÕES}

Existe efeito do genótipo no desenvolvimento in vitro de plântulas de diplóides de bananeira obtidos a partir de cultura de embriões.

As progênies dos genótipos selvagens do grupo BB apresentam maior desenvolvimento in vitro do que aquelas dos híbridos do grupo AA e estas em relação às progênies dos materiais silvestres do mesmo grupo (AA).

A progênie do genótipo Butuhan apresentou melhor desempenho nas condições de cultura utilizadas.

O protocolo utilizado para o resgate de embriões das progênies (genótipos) estudadas foi adequado, devendo o período de desenvolvimento in vitro ser reduzido para 30 dias.

TABELA 1 - Desenvolvimento in vitro de plântulas de oito genótipos diplóides de bananeira proveniente de cultura de embriões. Embrapa Mandioca e Fruticultura, 1998.

\begin{tabular}{|c|c|c|c|c|c|c|}
\hline Genótipos & $\begin{array}{c}\text { A ltura } \\
(\mathbf{c ~ m})\end{array}$ & $\begin{array}{l}\text { Núm ero } \\
\text { de Folhas }\end{array}$ & $\begin{array}{c}\text { Núm erode } \\
\text { raízes }\end{array}$ & $\begin{array}{c}\text { Comprimento } \\
\text { maior raiz (c m) }\end{array}$ & $\begin{array}{c}\text { Pesoseco } \\
\text { da r a iz }(\mathrm{mg})^{2}\end{array}$ & $\begin{array}{l}\text { P esoseco par - } \\
\text { te a érea }(\mathrm{mg})^{2}\end{array}$ \\
\hline Butuhan & $6,17 \mathrm{a}$ & $5,74 b$ & $15,24 b$ & $23,34 \mathrm{a}$ & $0,19 \mathrm{a}$ & $0,22 \mathrm{a}$ \\
\hline França & $4,21 \mathrm{~b}$ & $5,12 b$ & $14,41 \mathrm{~b}$ & $17,12 b$ & $0,18 b$ & $0,20 \mathrm{~b}$ \\
\hline $0304-02$ & $4,04 \mathrm{~b}$ & $5,65 b$ & $17,18 \mathrm{~b}$ & $12,23 \mathrm{c}$ & $0,19 \mathrm{a}$ & $0,19 \mathrm{c}$ \\
\hline $4252-04$ & $4,00 \mathrm{~b}$ & $5,77 b$ & $19,41 \mathrm{a}$ & $15.00 \mathrm{~b}$ & $0,19 \mathrm{a}$ & $0,19 \mathrm{c}$ \\
\hline $1304-06$ & $3,54 \mathrm{c}$ & $6,41 \mathrm{a}$ & $16,41 \mathrm{~b}$ & $12,39 \mathrm{c}$ & $0,19 \mathrm{a}$ & $0,19 \mathrm{c}$ \\
\hline $9379-09$ & $3,11 \mathrm{c}$ & $6,47 \mathrm{a}$ & $14,35 b$ & $17,13 b$ & $0,19 \mathrm{a}$ & $0,19 \mathrm{c}$ \\
\hline $\mathrm{Ca}$ lcutta & $2,90 \mathrm{c}$ & $5,29 b$ & $21,12 \mathrm{a}$ & $11,40 \mathrm{c}$ & $0,19 \mathrm{a}$ & $0,19 \mathrm{c}$ \\
\hline $\mathrm{M}$ a laccens is & $1,48 \mathrm{~d}$ & $3,94 \mathrm{c}$ & $15,70 \mathrm{~b}$ & $6,91 \mathrm{~d}$ & $0,18 b$ & $0,18 \mathrm{~d}$ \\
\hline Média geral & 3,68 & 5,54 & 16,72 & 14,44 & 0,19 & 0,19 \\
\hline C V (\%) & 31,19 & 23,11 & 31,35 & 27,09 & 3,82 & 4,18 \\
\hline
\end{tabular}

${ }^{1}$ Médias seguidas de mesma letra minúscula na coluna, não diferem entre si pelo teste de Scott Knott (1974) ao nível de 5\% de probabilidade.

${ }^{2}$ Dados transformados para $\log (\mathrm{x}+1,5)$

TABELA 2 - Estudo de correlação entre as variáveis altura de planta (ALT), número de folhas (NFO), número de raízes (NRA), comprimento da maior raiz (CMR), peso seco da raiz (PSR), e peso seco da parte aérea (PSA).em oito genótipos diplóides de banana. Embrapa Mandioca e Fruticultura, 1998.

\begin{tabular}{lcccccc}
\hline Variáveis $^{1}$ & ALT & NFO & NRA & CMR & PSR & PSA \\
\hline ALT & - & $0,19 \mathrm{~ns}$ & $-0,03 \mathrm{~ns}$ & $0,62^{* *}$ & $0,30 \mathrm{~ns}$ & $0,75^{* *}$ \\
NFO & & - & $0,23 \mathrm{~ns}$ & $0,22 \mathrm{~ns}$ & $0,28 \mathrm{~ns}$ & $0,28 \mathrm{~ns}$ \\
NRA & & & - & $-0,07 \mathrm{~ns}$ & $0,21 \mathrm{~ns}$ & $0,03 \mathrm{~ns}$ \\
CMR & & & & - & $0,29 \mathrm{~ns}$ & $0,65^{* *}$ \\
PSR & & & & & - & $0,32 \mathrm{~ns}$ \\
PSA & & & & & & - \\
\hline
\end{tabular}

\section{REFERÊNCIAS BIBLIOGRÁFICAS}

AFELE, J.C.; DE LANGHE, E. Increasing in vitro germination of Musa balbisiana seed. Plant Cell, Tissue and Organ Culture, Dordrecht, v.27, p.33-36, 1991.

CHIN, H.F. Germination and storage of banana seeds. In: FRISSON, E.A.; HORRY, J.P.; WAELE, D. (Eds.) New frontiers in resistance breeding for nematode, Fusarium and Sigatoka, Kuala Jampur, Malasia, 1995. Proceedings... Montpellier, France: IPGRI/ INIBAP/CIRAD/MARDI, 1996. P.218-227.

COX, E.A.; STOTZKY, G.; GOODS, R.D. In vitro culture of Musa balbisiana cola embryos. Nature, London, v.185, p.403-404, 1960.

FAO. Disponível: site. FAO. URL: http:/apps.fao.org. Consultado em 18 abr. 1999. 
HU, C.Y.; FERREIRA, A.G. Cultura de embriões. In: TORRES, A.C.; CALDAS, L.S. (Eds.) Técnicas e aplicações da cultura de tecidos de plantas. Brasília, ABCTP, EMBRAPA-CNPH, 1990. P.71-85.

JOHRI, B.M.; RAO, P.S. Experimental embryology. In: JOHRI, B.M. (Ed.) Embryology of angiosperms. Berlin, Springer-Verlag, 1984. P.744-802.

MURASHIGE, T.; SKOOG, F. A revised medium for rapid growth and biossays with tobacco tissue cultures. Physiologia Plantarum, Copenhagen, v.15, p.473-497, 1962.

NEVES, T.S.; SILVA, S.O.; OLIVEIRA, R.P. Avaliação do resgate in vitro de embriões em genótipos diplóides de bananeira. Revista Brasileira de Fisiologia Vegetal, 1998 (no prelo).

OLIVEIRA, R.P.; SILVA, S.O. Avaliação da microprogação comercial em bananeira. Pesquisa Agropecuária Brasileira, Brasília, v.32, n.4, p.415-420, 1997.

OLIVEIRA, R.P.; SILVEIRA, D.G.; SILVA, S.O.; SILVA, K.M.; VILARINHOS, A.D. Micropropagação in vitro de genótipos diplóides, triplóides e tetraplóides de bananeira. Pesquisa Agropecuária Brasileira, Brasília, 1998. (no prelo).

OLIVEIRA, R.P.; DANTAS, J.L.L.; ALMEIDA, E.P.; NICKEL, O.; VILARINHOS, A.D.; MORALES, C.F.G. Uso da biotecnologia no melhoramento genético e propagação do mamoeiro. In: MENDES, L.G.; DANTAS, J.L.L.; MORALES, C.F.G. Mamão no Brasil. Cruz das Almas, BA: EAUFBA/EMBRAPA-CNPMF, 1996, 1996.p.159-172.
RAGHAVAN, V. Embryo culture. In: BOHM, H. (Eds.) International Review of Citology. Colombus, Academic Press, n.11, 1980. P.209-239.

SCOTT, A.J.; KNOTT, M. A cluster analysis method for grouping means in the analysis os variance. Biometrics, v.30, p.507-512, 1974.

SHEPHERD, K.; DANTAS, J.L.L.; SILVA, S.O. Breeding of Prata and Maçã cultivars for Brazil. In: INIBAP. The improvement and testing of Musa; a global partnership. Honduras, 1994. P.157168 .

SILVA, S.O.; MATOS, A.P.; ALVES, E.J.; SHEPHERD, K. Breeding 'Prata' (Pomme) and 'Maçã' (Silk) banana types current achievements and opportunities. Infomusa, Montpellier, v.6, n.2, p.7-10, 1997.

SILVA, S.de O.; K. M. SILVA; BORGES, M. de F.; OLIVEIRA, R.P. Pollination and culture of banana embryos. Infomusa, Montpellier, v 8, n. 1, p 24-26, 1999.

STOTZKY, G.; COX, E.A.; GOOS, R.D. Seed germination studies in Musa. I. Scarification and aseptic germination of Musa balbisiana. American Journal of Botany, Massachusetts, v.49, n.5, p.512-520, 1962.

VUYLSTEKE, D., SWENNEN, R. Biotechnological approaches to plantain and banana improvement at IITA. In: Ceel and Tissue Culture, Ibadan, Nigeria, 1991. P.143-149. 